\title{
Anti-CCP Antibody Vs Rheumatoid Factor: A Comparison of Diagnostic Characteristics for Rheumatoid Arthritis
}

\author{
Kiran Bala*, Nitin Kumar, Aparna, Madhu Sharma, Ritu Aggarwal and Akshit Griwan
}

Department of Microbiology, Pt. B. D. Sharma PGIMS, Rohtak, Haryana, India

*Corresponding author

\section{A B S T R A C T}

\section{Key w o r d s \\ Anti-ccp, Rheumatoid arthritis, Rheumatoid factor, ELISA \\ Article Info \\ Accepted: 10 September 2018 Available Online: 10 October 2018}

Rheumatoid arthritis is a common systemic inflammatory disease and the diagnosis is primarily based on clinical manifestations. This study was conducted with the aim of comparison between rheumatoid factor (RF) and anti-ccp antibody tests for the diagnosis of Rheumatoid Arthritis. A total of 312 samples comprising 124 (39.7\%) from Rheumatoid arthritis patients and 188 (60.3\%) from non-Rheumatoid arthritis patients, were collected. Anti-ccp test was found to be better than Rheumatoid factor in sensitivity, specificity, Positive Predictive Value (PPV), Negative Predictive Value (NPV), Likelihood Ratio Positive, Likelihood Ratio Negative, False Positive Rate, False Negative Rate.

\section{Introduction}

Rheumatoid arthritis is the most common inflammatory polyarthritis and is prevalent in approximately $1 \%$ population globally (Klareskog and Catrina, 2009; Aswani et al., 2017). It is an autoimmune disease that occurs more commonly in women than men (Ronald, 2009).

Approximately $20-30 \%$ of untreated rheumatoid arthritis patients become permanently disabled (Rindfleisch and Muller, 2005). Thus, early and accurate diagnosis results in better treatment modality and lengthens healthy life. In 1998, Schelleken reported that antibodies, against citrullinated peptide, are highly specific seromarker for the diagnosis as well as prognosis of rheumatoid arthritis, before that rheumatoid factor (RF) was the only serological marker for the diagnosis of rheumatoid arthritis (Schellekens et al., 1998; Hill et al., 2003).

The diagnosis of rheumatoid arthritis depends primarily on the American College of Rheumatology (ACR) criteria.

A patient is considered to be suffering from rheumatoid arthritis if at least four of the seven criteria have been present for at least six weeks; of which the only laboratory test criterion is the presence of serum Rheumatoid Factor (RF) or anti ccp (Banal et al., 2009). Rheumatoid factor is $\operatorname{IgM}$ autoantibodies that are directed against $\mathrm{Fc}$ portion of $\mathrm{IgG}$ antibody, whereas anti ccp antibodies are IgG 
antibodies against citrullinated peptides. Anti ccp is not routine laboratory test in resource limited settings due to the less availability of related literature and skill requisite ELISA procedure compared with simple latex agglutination in RF test (Bineeta et al., 2015; Van Pruijn, 2000).

This study was conducted to compare RF with anti ccp antibody detection for the diagnosis of rheumatoid arthritis.

\section{Materials and Methods}

A total of 312 serum samples were collected from suspected cases of rheumatoid arthritis. Samples were subjected to RF detection by latex agglutination method and anti ccp antibody detection by Enzyme linked immune sorbent assay (ELISA) (Hotgen biotech, Beijing) as per manufacture instructions with the cut off at $8 \mathrm{IU} / \mathrm{ml}$ and $25 \mathrm{Units} / \mathrm{ml}$ respectively.

Diagnostic characteristics of both the tests were calculated in respect of sensitivity, specificity, Positive predictive value (PPV), Negative predictive value (NPV), Likelihood Ratio Positive, Likelihood Ratio Negative, False positive rate (FPR) and False negative rate (FNR) by SPSS software 20.0.

\section{Results and Discussion}

Out of 312 samples, $64(20.5 \%)$ were from males and $248(79.5 \%)$ were from females with male to female ratio of 1:4 (chart 1$)$.

A total of $124(39.7 \%)$ patients were diagnosed on the basis of American College of Rheumatology (ACR) criterion.

Most of the patients were between the age group of 41-50 years and it was found that rate of positivity increases as the age advances (chart 2). The results of RF and anti ccp antibodies were detected in $82.3 \%(96 / 124)$ and $83.1 \%(99 / 124)$ patients respectively. (Table 1 and 2).

The present study was conducted to facilitate the clinicians to confirm the diagnosis of rheumatoid arthritis.

Majority of the patients $(83.1 \%)$ were female that correlates with the studies conducted by (Sebbeg et al., 1995; Vincent et al., 1989; Nienhuis et al., 1964). In this study, incidence of rheumatoid arthritis was found to be high in age group above 60 years $(59.4 \%)$ and lower incidence in age group of 11-20 years (20\%). The mean age group of the patients was 46.2 years.

Rheumatoid factor was to be positive in $77.4 \%$ and anti-ccp antibodies were detected in $79.8 \%$ positive cases respectively, similar results $(77 \%$ and $81 \%)$ were reported by (Oommen et al., 2011). Another study by Ayisha et al., reported $76 \%$ \& $78 \%$ sensitivity of RF and anti-ccp test respectively (Ayesha, 2017).

Other studies conducted by Munevver et al., (65\%), Sibel et al., (60\%), Machold et al., $(55 \%)$ and Nehir et al., (44.8\%) have documented less sensitivity of anti ccp antibodies (Munevver et al., 2008; Sibel et al., 2004; Machold et al., 2007; Nehir et al., 2005).

This could be due to the method of selection of suspected cases. In present study, specificity of RF was found to be less $(82.4 \%)$ as compared to that of anti-ccp antibody (98.4\%). Our study goes parallel with the studies conducted by Ayesha et al., (86\%, 98.6\%), Sibel et al., (86.4\%, 98.6\%) and Lee et al., $(80.3 \%, 90 \%)$ of RF and anti-ccp antibodies (Ayesha, 2017; Sibel et al., 2004; Lee and Weisman, 2006). 
Table.1 Diagnostic characteristics of RF detection for the diagnosis of RA

\begin{tabular}{|c|c|c|c|c|c|c|c|c|c|c|}
\hline \multirow[t]{2}{*}{ RF test } & \multicolumn{2}{|c|}{ ACR criterion } & $\begin{array}{c}\text { Sensitivity } \\
(\%)\end{array}$ & $\begin{array}{c}\text { Specificity } \\
(\%)\end{array}$ & $\begin{array}{c}\text { Positive } \\
\text { Predictive } \\
\text { Value }\end{array}$ & $\begin{array}{c}\text { Negative } \\
\text { Predictive } \\
\text { Value }\end{array}$ & $\begin{array}{l}\text { Positive } \\
\text { likelihood } \\
\text { ratio }\end{array}$ & $\begin{array}{c}\text { Negative } \\
\text { likelihood } \\
\text { ratio }\end{array}$ & $\begin{array}{c}\text { False } \\
\text { positive } \\
\text { rate }\end{array}$ & $\begin{array}{c}\text { False } \\
\text { negative } \\
\text { rate }\end{array}$ \\
\hline & Positive & Negative & & & & & & & & \\
\hline Positive & 96 & 33 & 77.4 & 82.4 & 74.4 & 84.7 & 4.4 & 0.27 & 0.18 & 0.23 \\
\hline Negative & 28 & 155 & & & & & & & & \\
\hline
\end{tabular}

Table.2 Diagnostic characteristics of anti-CCP antibody detection for the diagnosis of RA

\begin{tabular}{|c|c|c|c|c|c|c|c|c|c|c|}
\hline \multirow{2}{*}{$\begin{array}{l}\text { Anti- } \\
\text { CCP } \\
\text { test }\end{array}$} & \multicolumn{2}{|c|}{ ACR criterion } & \multirow[t]{2}{*}{$\begin{array}{c}\text { Sensitivity } \\
(\%)\end{array}$} & \multirow[t]{2}{*}{$\begin{array}{c}\text { Specificity } \\
(\%)\end{array}$} & \multirow[t]{2}{*}{$\begin{array}{c}\text { Positive } \\
\text { Predictive } \\
\text { Value } \\
(\%)\end{array}$} & \multirow[t]{2}{*}{$\begin{array}{c}\text { Negative } \\
\text { Predictive } \\
\text { Value } \\
(\%)\end{array}$} & \multirow{2}{*}{$\begin{array}{l}\text { Positive } \\
\text { likelihood } \\
\text { ratio }\end{array}$} & \multirow{2}{*}{$\begin{array}{c}\text { Negative } \\
\text { likelihood } \\
\text { ratio }\end{array}$} & \multirow{2}{*}{$\begin{array}{c}\text { False } \\
\text { positive } \\
\text { rate }\end{array}$} & \multirow{2}{*}{$\begin{array}{c}\text { False } \\
\text { negative } \\
\text { rate }\end{array}$} \\
\hline & Positive & Negative & & & & & & & & \\
\hline Positive & 99 & 3 & 79.8 & 98.4 & 97.1 & 88.1 & 50.0 & 0.2 & 0.02 & 0.2 \\
\hline Negative & 25 & 185 & & & & & & & & \\
\hline
\end{tabular}


Chart.1 Gender wise distribution of rheumatoid arthritis

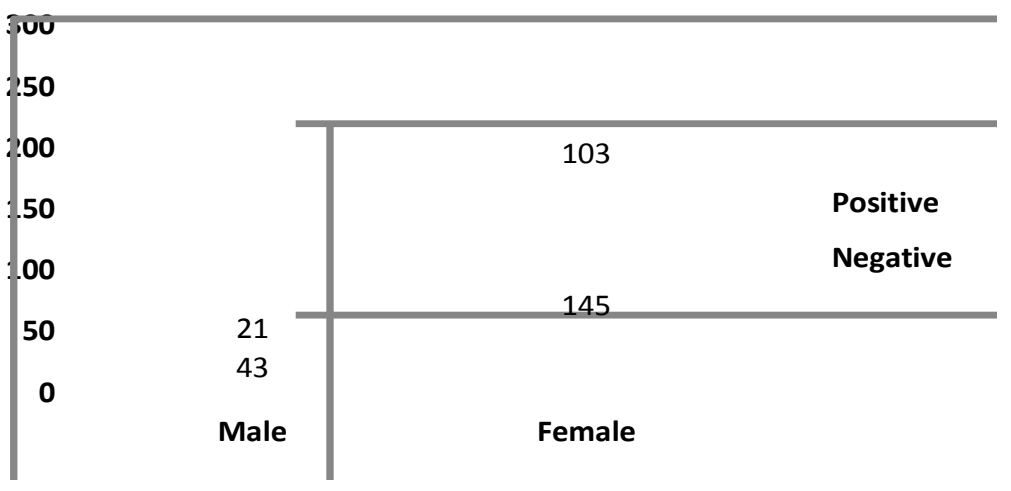

Chart.2 Age wise distribution of rheumatoid arthritis

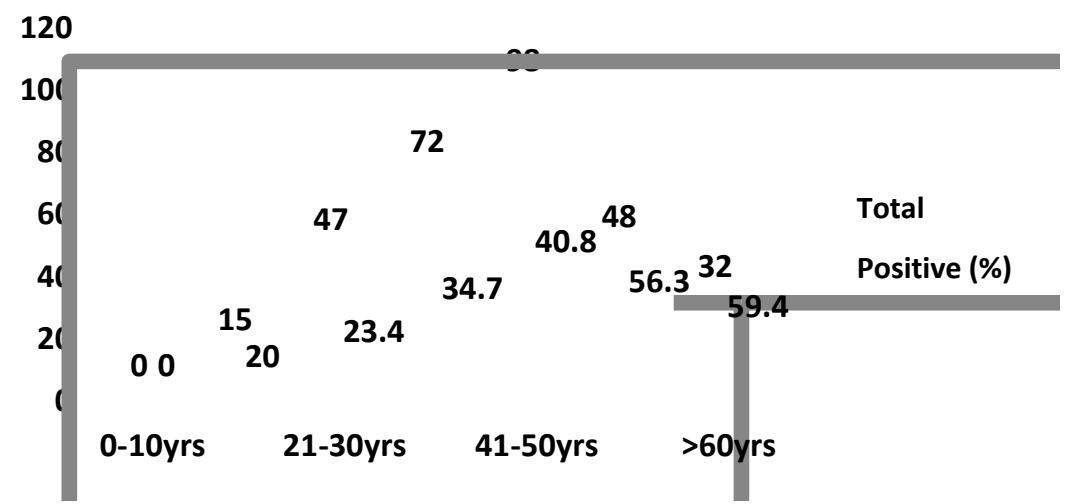

The present study concludes that detection of anti-ccp antibodies is an important test and may help the clinicians to make early detection and management of Rheumatoid arthritis.

Funding: None

Conflict of Interest: None declared

Ethical approval: None declared

\section{References}

Aswani K, Ankita A, Sae S et al., RF and AntiCCP Antibody Tests- A comparative study in the Diagnosis of Rheumatoid Arthritis in a Tertiary Care Hospital. International Journal of Medical Microbiology and Tropical Diseases. 2017; 3(4):137-139.

Ayesha D. Comparison of Anti CCP Positivity in RA and Other Arthritic Patients
Including Connective Tissue Disorders. Int.J.Curr.Microbiol.App.Sci 6(10): 2461-2473.

(2017)

Banal, F., M. Dougados, C. Combescure, and L. Gossec, "Sensitivity and specificity of the American College of Rheumatology 1987 criteria for the diagnosis of rheumatoid arthritis according to disease duration: a systematic literature review and metaanalysis," Annals of the Rheumatic Diseases 2009; 68(7):1184-1191.

Bineeta K, Urvashi T et al., Diagnostic utility of anti-CCP antibodies and rheumatoid factor as inflammatory biomarkers in comparison with $\mathrm{C}$-reactive protein and TNF- $\alpha$ in rheumatoid arthritis. Trop J Med Res 2015; 18:5-9

Hill, J.A., Southwood, S., Sette, A. 2003. Cutting edge: the conversion of arginine to citrulline allows for a high- 
affinity peptide interaction with the rheumatoid arthritis-associated HLADRB1*0401 MHC class II molecule. J. Immunol., 171: 538-41

Klareskog L, and Catrina IA, Paget S. Rheumatoid arthritis. The Lan-cet 2009; 373: 659-72.

Lee $\mathrm{W}$, and Weisman MH. The predictive power of anti-cyclic citrullinated peptide antibodies: Window into understanding gene/environment/immunity interactions. J Rheumatol 2006; 33; 1216-8

Machold KP, Stamm TA, Nell VP et al., Very recent onset rheumatoid arthritis: clinical and serological patient characteristics associated with radiographic progression over the first years of disease. Rheumatology. 2007; 46:342-9

Münevver $\mathrm{S}$ et al., the association of anti-ccp antibodies with disease activity in rheumatoid arthritis. Rheumatol int, 2008; 28: 965-970.

Nehir S, Sebahat O. Halide A et al., Diagnostic value and clinical significance of anti-ccp in patients with advanced rheumatoid arthritis. J Natl Med Assoc. 2005 Aug; 97(8): 1120-1126.

Nienhuis R, Mandema E, Smids C. New serum factor in patients with rheumatoid arthritis: the antiperinuclear factor. Annals of the rheumatic diseases 1964, 23(4):302

Oommen S, Appalaraju B et al., A combined diagnostic approach to Rheumatoid arthritis using anti-cyclic citrullinated peptide antibodies and rheumatoid factor. Indian J Med Microbiol 2011; 29:195-6.
Rindfleisch J. A. and D. Muller, "Diagnosis and management of rheumatoid arthritis," American Family Physician, vol. 72, no. 6, pp. 1037-1047, 2005.

Ronald F. Sex differences in rheumatoid arthritis: more than meets the eye. BMC Med. 2009; 7: 12

Schellekens, G.A., de Jong, B.A.W., van den Hoogen, F.H.J. 1998. Citrulline is an essential constituent of antigenic determinants recognized by rheumatoid arthritis-specific autoantibodies. J. Clin. Invest, 101: 273-81

Sebbag M, Simon M, Vincent C, Masson B, Girbal E, Durieux J, Serre G: The antiperinuclear factor and the so-called antikeratin antibodies are the same rheumatoid arthritis-specific autoantibodies. The Journal of Clinical Investigation 1995, 95(6): 2672-2679.

Sibel A., Reyhan C et al., a new marker in Rheumatoid Arthritis- autoimmunity relation: anticyclic citrullinated peptide antibody. Turk j immunol; 2004; 9: 21265.

Van V, and Pruijn GJ. Citrullination: a small change for a protein with great consequences for rheumatoid arthritis. Arthritis research 2000, 2(4):249-2

Vincent C, Serre G, Lapeyre F, Fournié B, AyrollesC, Fournié A, Soleilhavoup J. High diagnostic value in rheumatoid arthritis of antibodies to the stratum corneum of rat oesophagus epithelium, so-called' antikeratin antibodies'. Annals of the rheumatic diseases 1989, 48(9):712-722.

\section{How to cite this article:}

Kiran Bala, Nitin Kumar, Aparna, Madhu Sharma, Ritu Aggarwal and Akshit Griwan. 2018. AntiCCP Antibody Vs Rheumatoid Factor: A Comparison of Diagnostic Characteristics for Rheumatoid Arthritis. Int.J.Curr.Microbiol.App.Sci. 7(10): 1095-1099. doi: https://doi.org/10.20546/ijcmas.2018.710.120 